\title{
PENDEKATAN TEORITIS ANALISIS SUMBER-SUMBER INFLASI
}

\section{Dr. Jonni Manurung}

\begin{abstract}
Dr. Jonni Manurung, The Theory Approach of Inflation Determinant Analysis has the goal to identify the sources of inflation and finding the alternative policy strategy to stabilizing the inflation. According to the inflation decomposition, the source of inflation is core or underlying inflation, noncore inflation, and noise inflation. According to the expected-augmented Phillips curve, the deviation of inflation to the expected inflation is sourced from supply shocks, the deviation of economic growth rate to the natural rate, and the deviation of unemployment rate to the natural rate. According to the dynamic monetary policy inconsistent, inflation is sourced from inflation target, the deviation of economic growth rate to natural rate, the deviation of unemployment rate to natural rate, and supply shock. According to the credibility monetary policy, inflation is sourced from expected inflation and the deviation of economic growth rate to natural rate.
\end{abstract}

According to the inflation composition, the deviation of inflation to expected inflation is sourced from noncore inflation and noise inflation. So that the relation between the expected-augmented Phillips curvel, the dynamic monetary policy inconsistent, and the credibility monetary policy is show that the noncore inflation and the noise inflation determined by the deviation of economic growth rate to natural rate, the deviation of unemployment rate to natural rate, and supply shock. The conclution of this theory is show that the equilibrium in economic growth target and economic growth to natural rate, unemployment rate to natural rate is create the equilibrium in inflation and expected inflation. So the alternative policy stategy is increase in economic growth to the natural rate or decrease unemployment rate to the natural rate. From the side of inflation decomposition, increase in economic growth to the natural rate or decrease in unemployment rate to the natural rate is the same to maintaine the stabilizing in administered inflation, volatile food inflation, and traded goods inflation.

From the side monetary policy, the stabilizing in volatile food inflation and traded goods inflation is created if increasing in monetary growth directed to small and medium business, because the small and medium business is absorpt more employment than the big business. From the side fiscal policy, the stabilizing in administered inflation is created if the government can eliminate the corruption in government projects. Eliminating the corruption in government projects will eliminate increase in price of strategic commodities, and it increase in social welfare.

Keywords: Determinant and Strategic Policy to Stabilizing Inflation.

\section{PENDAHULUAN}

Sasaran kebijakan ekonomimakro memiliki keterkaitan satu sama lain, sehingga membentuk suatu keseimbangan dalam perekonomian. Pertumbuhan ekonomi, peningkatan kesempatan kerja, stabilitas harga dan neraca permbayaran merupakan sebagian dari sasaran kebijakan ekonomimakro. Pada tingkat regional, pencapaian sasaran tidak hanya dipengaruhi oleh kebijakan ekonomimakro nasional, akan tetapi juga dipengaruhi oleh kebijakan ekonomi di bidang keuangan dan anggaran daerah, serta faktor-faktor lainnya yang menjadi kekhasan masing-masing daerah.

Barometer perekonomian riil yang tercermin dalam inflasi masih sangat rentan terhadap tekanan-tekanan permintaan yang melebihi kapasitas sekaligus rentan terhadap tekanan kenaikan biaya produksi baik akibat kelangkaan bahan produksi, bahan pendukung maupun biaya ekstra akibat buruknya infrastruktur pendukung usaha. Dilihat melalui penyebabnya, 
inflasi secara umum dapat dibedakan menjadi dua, yaitu inflasi tarikan permintaan atau demand pull inflation dan inflasi desakan biaya produksi atau cost push inflation. Demand pull inflation terjadi akibat adanya permintaan total yang berlebihan sehingga terjadi perubahan pada tingkat harga. Bertambahnya permintaan terhadap barang dan jasa mengakibatnya bertambahnya permintaan terhadap faktor-faktor produksi. Bertambahnya permintaan terhadap faktor-faktor produksi itu kemudian menyebabkan harga-harga faktor produksi naik. Oleh sebab itu inflasi ini terjadi karena suatu kenaikan dalam permintaan total sewaktu perekonomian yang bersangkutan dalam situasi full employment. Adapun cost push inflation terjadi akibat meningkatnya biaya produksi atau input sehingga mengakibatkan harga-harga produk atau output yang dihasilkan ikut naik.

Inflasi sebenarnya memiliki dampak netral, artinya dapat berdampak positip atau negatip. Apabila inflasi itu ringan, justru dapat mendorong perekonomian lebih baik, yaitu meningkatkan produksi nasional dan membuat orang bergairah untuk bekerja, menabung dan mengadakan investasi. Sebaliknya jika angka inflasi sangat tinggi dan tidak terkendali atau hyperinflation, maka bahaya perekonomian muncul baik dalam periode jangka pendek maupun dalam periode jangka panjang.

Bank sentral memainkan peranan penting dalam mengendalikan inflasi. Bank sentral suatu negara pada umumnya berusaha mengendalikan tingkat inflasi pada tingkat yang wajar. Beberapa bank sentral bahkan memiliki kewenangan yang independen dalam artian bahwa kebijakan tidak boleh diintervensi oleh pihak di luar bank sentral, termasuk pemerintah. Bank sentral umumnya mengandalkan jumlah uang beredar dan atau tingkat bunga sebagai instrumen dalam mengendalikan tingkat harga. Selain itu, bank sentral juga berkewajiban mengendalikan nilai tukar matauang domestik. Hal ini disebabkan karena nilai satu matauang dapat bersifat internal yang dicerminkan tingkat inflasi dan kondisi ekonomi eksternal, yaitu nilai tukar matauang.

Pentingnya pengendalian inflasi didasarkan pada pertimbangan bahwa inflasi yang tinggi dan tidak stabil memberikan dampak negatip kepada kondisi sosial ekonomi. Pertama, inflasi yang tinggi akan menyebabkan pendapatan riil masyarakat akan terus tergerus sehingga standar hidup dari masyarakat turun dan akhirnya menjadikan semua orang, terutama orang miskin, bertambah miskin. Kedua, inflasi yang tidak stabil akan menciptakan ketidakpastian bagi pelaku ekonomi dalam mengambil keputusan. Pengalaman empiris menunjukkan bahwa inflasi yang tidak stabil akan menyulitkan keputusan masyarakat dalam melakukan konsumsi, investasi dan produksi, yang pada akhirnya akan menurunkan pertumbuhan ekonomi. Ketiga, tingkat inflasi domestik yang lebih tinggi dibandingkan dengan tingkat inflasi di luar negeri menjadikan harga-harga barang dan jasa domestik relatif lebih mahal dibandingkan dengan harga-harga barang dan jasa luar negeri dan menekan neraca perdagangan.

Inflation Targetting Framework [ITF] telah diterapkan oleh Bank Indonesia sejak Juni 2005. Pemberlakuan ITF diyakini membantu Bank Indonesia untuk mencapai dan memelihara kestabilan harga dengan menentukan sasaran kebijakan moneter secara eksplisit berdasarkan proyeksi dan target inflasi tertentu. Dengan demikian, ekspektasi inflasi bukan melihat ke belakang atau backward looking, akan tetapi ekspektasi inflasi mengacu pada sasaran ke depan atau forward looking, yaitu sebagai sinyalnya adalah tingkat BI rate yang di-review dan diumumkan setiap bulan. Namun demikian, kendali Bank Indonesia atas inflasi masih terbatas, karena inflasi dipengaruhi oleh banyak faktor. Oleh karena itu, Bank Indonesia selalu melakukan penilaian terhadap perkembangan perekonomian, khususnya terhadap 
kemungkinan tekanan inflasi, dan respons kebijakan moneter didasarkan kepada hasil penilaian tersebut. Pengendalian inflasi tidak bisa dilakukan hanya melalui kebijakan moneter, melainkan juga kebijakan ekonomimakro lainnya, antara lain kebijakan fiskal dan kebijakan di sektor riil. Oleh sebab itu koordinasi dan kerjasama antar lembaga lintas sektoral sangatlah penting dalam menangani masalah inflasi. Identifikasi sumber-sumber tekanan inflasi khususnya di sisi penawaran menjadi informasi sangat penting dalam upaya pengendalian inflasi. Proyeksi inflasi ke depan pun menjadi informasi yang sangat penting, karena pengendalian inflasi bersifat forward looking, bukan backward looking.

Dalam kasus yang sering terjadi di Indonesia, gejala peningkatan inflasi dapat diakibatkan oleh gangguan distribusi, serangan hama atau gangguan alam lainnya. Dalam kasus seperti ini kebijakan kontraksi moneter justru akan membawa dampak yang negatip bagi upaya menakan laju inflasi dan mengurangi fluktuasi output itu sendiri. Meskipun tujuannya ingin menstabilkan inflasi dan output, namun demikian langkah-langkah kontraksi likuiditas akan membawa dampak negatip bagi sisi penawaran atau produksi sehingga justru akan semakin meningkatkan tekanan inflasi itu sendiri.

Data empiris setiap negara atau daerah menjelaskan bahwa permasalah utama inflasi adalah faktor-faktor apa penyebab peningkatan harga-harga umum atau inflasi dan bagaimana kontribusi faktor-faktor penyebab perkembangan harga-harga umum atau inflasi. Sumber tekanan harga-harga umum atau inflasi dibedakan atas karakteristik harga-harga atau inflasi inti atau exclusion or core inflation, inflasi non inti atau exclude items or uncore inflation, inflasi akibat kebijakan pemerintah atau administered inflation, inflasi karena gejolak harga makan atau volatile food inflation, inflasi karena harga-hargarang dagangan atau traded goods inflation. Di lain pihak, sumber tekanan harga-harga umum atau inflasi juga dapat dibedakan atas harga-harga atau inflasi komoditas bahan makanan, harga-harga atau inflasi komoditas makanan jadi, minuman, rokok dan tembakau, harga-harga atau inflasi komoditas perumahan, air, listrik, gas dan bahan bakar, harga-harga atau inflasi komoditas sandang, harga-harga atau inflasi komoditas kesehatan, harga-harga atau inflasi komoditas pendidikan, rekreasi dan olahraga, dan harga-harga atau inflasi komoditas transportasi, komunikasi dan jasa keuangan.

Secara geografis, Indonesia merupakan negara luas dan terdiri dari beberapa daerah otonom. Dalam upaya mengimplementasikan kebijakan moneter, Bank Indonesia perlu mendapat masukan akan perilaku inflasi dari daerah otonom. Disisi lain kebijakan otonomi daerah bertujuan untuk memberikan kewenangan dan tanggungjawab daerah dalam penglolaan ekonomi daerah masing-masing. Bank Indonesia dan pemerintah daerah memerlukan informasi yang berkaitan dengan perilaku dan perkembangan harga-harga umum atau inflasi daerah, guna menyusun target-target pembangunan yang ingin dicapai. Oleh sebab itu studi tentang perilaku dan perkembangan harga-harga umum atau inflasi di berbagai daerah dengan cara memisahkan berbagai karakteristik dan sumber-sumber utama tekanan terhadap inflasi serta pengukuran inflasi itu sendiri perlu dilakukan.

Permasalahan utama inflasi adalah karakteristik dan sumber-sumber utama tekanan terhadap inflasi serta alternatif strategi kebijakan untuk mengurangi tekanan inflasi. Oleh sebab itu rumusan permasalahan dalam studi ini adalah bagaimana kontribusi ekspektasi inflasi, pertumbuhan ekonomi dan pengangguran terhadap inflasi dan alternatif strategi kebijakan apa yang dapat digunakan untuk mengurangi tekanan inflasi.

MODEL TEORITIS 
Inflasi adalah kecenderungan dari harga-harga untuk meningkatkan secara umum dan terus menerus. Kenaikan harga dari satu atau dua barang saja tidak dapat disebut inflasi kecuali bila kenaikan itu meluas atau mengakibatkan kenaikan pada harga barang dan jasa lainnya. Inflasi dapat terjadi karena kelebihan permintaan atau excess demand terhadap barang-barang dalam perekonomian secara keseluruhan (Gunawan, 1991). Inflasi juga merupakan kenaikan hargaharga yang terus menerus dari barang dan jasa secara umum, bukan satu jenis barang saja dan sesaat. Oleh sebab itu peningkatan harga secara sporadis bukan inflasi (Iswardono, 1990). Menurut Boediono (1995) inflasi adalah kecenderungan dari harga-harga untuk naik secara umum dan terus menerus.

Pada umumnya indikator dari inflasi adalah indeks harga konsumen dan indeks harga perdagangan besar. Indeks harga konsumen merupakan indikator yang umum digunakan untuk menggambarkan pergerakan harga. Perubahan indeks harga konsumen dari waktu ke waktu menunjukkan pergerakan harga dari barang dan jasa yang dikonsumsi masyarakat. Pengukuran indeks harga konsumen di Indonesia dilakukan melalui survei bulanan di 45 kota, di pasar tradisional dan modern terhadap komoditas yang dikonsumsi oleh masyarakat untuk mengukur perubahan indeks harga konsumen. Indeks harga perdagangan besar merupakan indikator yang menggambarkan pergerakan harga dari komoditas yang diperdagangkan di suatu daerah.

\section{Dekomposisi Inflasi}

Karakteristik inflasi dikelompokkan menjadi inflasi inti atau core or underlying inflation, inflasi non inti atau noncore inflation dan inflasi sesaat atau noise inflation. Ada dua konsep yang dianut untuk memahami pengertian inflasi inti, yaitu inflasi inti sebagai komponen inflasi yang cenderung menetap atau persistent component di dalam setiap mengukur pergerakan laju inflasi dan inflasi inti sebagai kecenderungan perubahan harga secara umum atau generalized component. Oleh sebab itu dekomposisi inflasi inti dibedakan menjadi dua komponen, yaitu komponen menetap dan temporer. Komponen menetap ini terkait dengan kondisi penawaran dan permintaan dalam perekonomian. Dalam kaitan ini, komponen menetap dari inflasi berperan sangat penting dalam membentuk ekspektasi inflasi masyarakat, sedangkan komponen temporer kurang berperan karena tidak bisa diantisipasi dengan baik oleh masyarakat.

Komponen kecenderungan perubahan harga-harga secara umum atau generalized component juga terdiri dari dua komponen, yaitu komponen inflasi inti yang terkait dengan ekspektasi inflasi dan kebijakan moneter, serta komponen perubahan harga relatif terutama gangguangangguan dari sisi penawaran yang dipandang sebagai inflasi sesaat atau noise inflation karena secara teori perubahan harga relatif tidak menyebabkan terjadinya kecenderungan kenaikan harga-harga secara umum, kecuali diakomodasikan dalam kebijakan moneter. Kedua konsep tersebut akan memberikan hasil pengukuran inflasi yang terkait dengan ekspektasi inflasi masyarakat dan tekanan-tekanan dari sisi permintaan agregat, serta membuang unsur-unsur gangguan dari sisi penawaran. Hal ini berarti bahwa laju inflasi dapat didekomposisikan sebagai berikut:

$$
\begin{aligned}
& \pi=\kappa \pi_{\mathrm{C}}+[1-\kappa] \pi_{\mathrm{NC}}+\pi_{\mathrm{NO}} \\
& \pi_{\mathrm{NC}}=\theta_{1} \pi_{\mathrm{AD}}+\theta_{2} \pi_{\mathrm{FV}}+\left[1-\theta_{1}-\theta_{2}\right] \pi_{\mathrm{TG}}
\end{aligned}
$$

dimana $\pi$ = tingkat inflasi atau baseline inflation, $\pi_{\mathrm{C}}=$ inflasi inti atau core or underlying inflation, $\pi_{\mathrm{NC}}=$ inflasi bukan inti atau non core inflation, $\pi_{\mathrm{NO}}=$ inflasi sesaat atau noise inflation, $\pi_{\mathrm{AD}}=$ 
inflasi karena kebijakan harga-harga pemerintah atau administered inflation, $\pi_{\mathrm{FV}}=$ inflasi karena gejolak harga makanan atau volatile food inflation, $\pi_{\mathrm{TG}}=$ inflasi yang bersumber dari perdagangan atau traded goods inflation, $\kappa, \theta_{1}$ dan $\theta_{2}$ masing-masing adalah imbangan karakteristik inflasi terhadap baseline inflation.

The Expected-Augmented Phillips Curve

Menurut Lucas (1972, 1973, 1981), kesalahan persepsi moneter timbul karena individu tidak memiliki informasi sempurna tentang kondisi ekonomi. Misalnya seorang produsen tidak mengetahui penyebab perubahan harga produk di pasar, apakah disebabkan oleh perubahan permintaan agregat atau perubahan harga relatif permintaan produk yang bersangkutan. Misalkan $\mathrm{p}_{\mathrm{t}}[\mathrm{z}]$ adalah logaritme harga periode $[\mathrm{t}]$ dari produk $\mathrm{z}$ dan harga $\left[\mathrm{p}_{\mathrm{t}}\right]$ adalah logaritme harga umum pada periode $[t]$. Penawaran produk $\mathrm{z}$ pada periode [ $\mathrm{t}$ ] berhubungan positip dengan harga umum $\left[p_{t}(z)-p_{t}\right]$ jika individu penjual mengetahui nilai $p_{t}$. Lucas mengasumsikan bahwa penjual tidak mengetahui nilai $p_{t}$ sehingga harga umum merupakan suatu ekspektasi, yaitu $E_{t} p_{t}$ pada pasar produk z. Artinya penjual tidak mempunyai informasi sempurna, penjual hanya mempunyai informasi sempurna tentang harga produk $\mathrm{z}$ yang tersedia pada periode sebelumnya. Ekspektasi atau persepsi rasional dari $\mathrm{p}_{\mathrm{t}}$ pada $\mathrm{z}$ adalah

$$
\begin{aligned}
E_{\mathrm{t}} \mathrm{p}_{\mathrm{t}} & =\mathrm{E}\left[\mathrm{p}_{\mathrm{t}} \mid \mathrm{p}_{\mathrm{t}}(\mathrm{z}), \Omega_{\mathrm{t}-1}\right] \\
& =\phi \mathrm{p}_{\mathrm{t}}(\mathrm{z})+[1-\phi] \mathrm{E}_{\mathrm{t}-1} \mathrm{p}_{\mathrm{t}}
\end{aligned}
$$

dimana ekspektasi harga umum $\left[E_{z} p_{t}\right]$ merupakan rata-rata tertimbang dari harga produk $z$ dan ekspektasi harga umum pada periode sebelumnya $\left[\mathrm{E}_{\mathrm{t}-1} \mathrm{p}_{\mathrm{t}}\right]$. Kombinasi dari dua hubungan tersebut menjelaskan penawaran produk [z], yaitu:

$$
\begin{aligned}
& \mathrm{y}_{\mathrm{t}}(\mathrm{z})=\mathrm{y}(\mathrm{z})+\lambda\left[\mathrm{p}_{\mathrm{t}}(\mathrm{z})-\mathrm{p}_{\mathrm{t}}\right] \\
& \quad=\mathrm{y}(\mathrm{z})+\lambda\left[\mathrm{p}_{\mathrm{t}}(\mathrm{z})-\phi \mathrm{p}_{\mathrm{t}}(\mathrm{z})-(1-\phi) \mathrm{E}_{\mathrm{t}-1} \mathrm{p}_{\mathrm{t}}\right] \\
& =\mathrm{y}(\mathrm{z})+\lambda(1-\phi)\left[\mathrm{p}_{\mathrm{t}}(\mathrm{z})-\mathrm{E}_{\mathrm{t}-1} \mathrm{p}_{\mathrm{t}}\right]
\end{aligned}
$$

dimana $\mathrm{y}(\mathrm{z})$ dan $\lambda$ masing-masing merupakan penawaran output normal $\mathrm{z}$ dan konstanta positip. Apabila pasar secara agregat adalah monopoli sehingga semua produk mempunyai penawaran yang sama. Model penawaran agregat $\left[\mathrm{y}_{\mathrm{t}}\right]$ adalah

$$
\mathrm{y}_{\mathrm{t}}=\mathrm{y}+\lambda(1-\phi)\left[\mathrm{p}_{\mathrm{t}}-\mathrm{E}_{\mathrm{t}-1} \mathrm{p}_{\mathrm{t}}\right]
$$

Bentuk terakhir dari (4) merupakan teori kesalahan persepsi penawaran agregat dari Lucas. Penawaran agregat $\left[\mathrm{y}_{\mathrm{t}}\right]$ relatif tinggi terhadap output normal jika $\mathrm{p}_{\mathrm{t}}$ lebih besar dari $\mathrm{E}_{\mathrm{t}-\mathrm{i}} \mathrm{p}_{\mathrm{t}}$. Diketahui nilai $\mathrm{E}_{\mathrm{t}-1} \mathrm{p}_{\mathrm{t}}=\mathrm{p}_{\mathrm{t}-1}$ sehingga fungsi penawaran agregat (4) berubah menjadi:

$$
\begin{aligned}
{\left[\mathrm{p}_{\mathrm{t}}-\mathrm{E}_{\mathrm{t}-1} \mathrm{p}_{\mathrm{t}}\right] } & =\left[\mathrm{p}_{\mathrm{t}}-\mathrm{p}_{\mathrm{t}-1}-\mathrm{E}_{\mathrm{t}-1} \mathrm{p}_{\mathrm{t}}+\mathrm{p}_{\mathrm{t}-1}\right] \\
& =\left[\mathrm{p}_{\mathrm{t}}-\mathrm{p}_{\mathrm{t}-1}\right]-\left[\mathrm{E}_{\mathrm{t}-1} \mathrm{p}_{\mathrm{t}}-\mathrm{E}_{\mathrm{t}-1} \mathrm{p}_{\mathrm{t}-1}\right] \\
& =\Delta \mathrm{p}_{\mathrm{t}}-\mathrm{E}_{\mathrm{t}-1} \Delta \mathrm{p}_{\mathrm{t}}
\end{aligned}
$$

Substitusi (5) ke (4) akan menghasilkan penawaran agregat sebagai fungsi dari deviasi inflasi aktual dengan ekspektasi inflasi, yaitu:

$$
\begin{aligned}
\mathrm{y}_{\mathrm{t}} & =\mathrm{y}+\lambda(1-\phi)\left[\Delta \mathrm{p}_{\mathrm{t}}-\mathrm{E}_{\mathrm{t}-1} \Delta \mathrm{p}_{\mathrm{t}}\right] \\
& =\mathrm{y}+\alpha\left[\pi_{\mathrm{t}}-\pi_{\mathrm{t}}\right]
\end{aligned}
$$

Persamaan (6) merupakan pengembangan dari kurva Phillips yang menjelaskan bahwa ouput agregat aktual akan lebih tinggi dari output normal jika tingkat inflasi aktual pada periode [t] lebih tinggi dari ekspektasi inflasi pada periode [t]. Koefisien $\alpha$ merupakan ukuran kemiringan kurva Phillips dan $\left[\pi_{\mathrm{t}}-\pi_{\mathrm{t}}\right.$ ] merupakan ukuran kejutan harga. Semakin besar $\alpha$ maka semakin besar pengaruh kejutan harga terhadap output agregat. Okun's Law menyatakan bahwa perbedaan output agregat aktual dengan output normal $\left[\mathrm{y}_{\mathrm{t}}-\mathrm{y}\right]$ akan semakin tinggi jika tingkat 
pengangguran $\left[\mathrm{u}_{\mathrm{t}}\right]$ semakin rendah. Dengan kata lain perbedaan tingkat inflasi aktual dengan ekspektasi inflasi yang semakin tinggi akan menghasilkan tingkat pengangguran yang semakin rendah, dan kemudian menghasilkan output agregat yang semakin tinggi, sehingga [ $\mathrm{y}_{\mathrm{t}}-\mathrm{y}$ ] semakin tinggi. Hipotesis ini mirip dengan hipotesis Friedman (1968). Model penawaran agregat atau kurva Phillips dari Lucas banyak digunakan sebagai alat analisis inflasi optimal untuk meminimumkan social loss function (Lippi, 1993; Rogoff, 1985, Obstfeld and Rogoff, 1996; Romer, 1996). Dalam studi ekonomimakro, penawaran agregat jangka panjang juga disebut the expected-augmented Phillips curve (Romer, 1996), yaitu:

$$
\begin{aligned}
& \mathrm{p}_{\mathrm{t}}=\mathrm{p}_{\mathrm{t}-1}+\pi_{\mathrm{t}}+\lambda\left[\mathrm{y}_{\mathrm{t}}-\mathrm{y}\right]-\gamma\left[\mathrm{u}_{\mathrm{t}}-\mathrm{u}\right]+\varepsilon_{\mathrm{t}} \\
& \mathrm{p}_{\mathrm{t}}-\mathrm{p}_{\mathrm{t}-1}=\pi_{\mathrm{t}}+\lambda\left[\mathrm{y}_{\mathrm{t}}-\mathrm{y}\right]-\gamma\left[\mathrm{u}_{\mathrm{t}}-\mathrm{u}\right]+\varepsilon_{\mathrm{t}} \\
& \pi_{\mathrm{t}}=\pi_{\mathrm{t}}^{*}+\lambda\left[\mathrm{y}_{\mathrm{t}}-\mathrm{y}\right]-\gamma\left[\mathrm{u}_{\mathrm{t}}-\mathrm{u}\right]+\varepsilon_{\mathrm{t}}
\end{aligned}
$$

dimana $\pi^{\circ},\left[y_{t}-y\right],\left[u_{t}-\mathrm{u}\right]$ dan $\varepsilon_{t}$ masing-masing adalah core or underlying inflation atau ekspektasi inflasi yang bersumber dari perubahan penawaran agregat, deviasi pertumbuhan ekonomi dengan pertumbuhan ekonomi alamiah juga memberikan tekanan terhadap inflasi, deviasi tingkat pengangguran dengan tingkat pengangguran alamiah, dan kejutan penawaran agregat. Karateristik inflasi akibat perubahan deviasi pertumbuhan ekonomi dengan pertumbuhan ekonomi alamiah dan deviasi tingkat pengangguran dengan tingkat pengangguran alamiah merupakan komponen temporer dari core or underlying inflation, karena sumber inflasi ini akan hilang jika deviasi pertumbuhan ekonomi dan deviasi pengangguran tidak ada. Oleh sebab itu baseline inflation $\left[\pi_{\mathrm{t}}\right]$ terdiri dari komponen menetap dari core or underlying inflation $\left[\pi_{\mathrm{t}}^{\mathrm{t}}\right]$ dan komponen temporer dari core or underlying inflation $\left[\lambda\left(\mathrm{y}_{\mathrm{t}}-\mathrm{y}\right)-\gamma\left(\mathrm{u}_{\mathrm{t}}\right.\right.$ $\mathrm{u})$ ], serta noise inflation $\left[\varepsilon_{\mathrm{t}}\right]$ yang bersumber dari kejutan penawaran dan permintaan agregat.

Core or underlying inflation juga dikarakteristikkan sebagai rata-rata tertimbang ekspektasi inflasi dan inflasi periode sebelumnya $\left[\theta \pi_{\mathrm{t}}+(1-\theta) \pi_{\mathrm{t}-1}\right]$. Rata-rata tertimbang ekspektasi inflasi dan inflasi periode sebelumnya disebut inertia in wage and price inflation. Oleh sebab itu baseline inflation juga dapat dirumuskan sebagai berikut:

$$
\begin{aligned}
\pi_{\mathrm{t}} & =\pi_{\mathrm{t}}+\lambda\left[\mathrm{y}_{\mathrm{t}}-\mathrm{y}\right]-\gamma\left[\mathrm{u}_{\mathrm{t}}-\mathrm{u}\right]+\varepsilon_{\mathrm{t}} \\
& =\theta \pi_{\mathrm{t}}+(1-\theta) \pi_{\mathrm{t}-1}+\lambda\left[\mathrm{y}_{\mathrm{t}}-\mathrm{y}\right]-\gamma\left[\mathrm{u}_{\mathrm{t}}-\mathrm{u}\right]+\varepsilon_{\mathrm{t}}
\end{aligned}
$$

Core or underlying inflation juga dapat dikarakteristikkan sebagai inflasi periode sebelumnya [ $\pi_{\mathrm{t}}$ 1], sehingga baseline inflation dirumuskan menjadi:

$$
\pi_{\mathrm{t}}=\pi_{\mathrm{t}-1}+\lambda\left[\mathrm{y}_{\mathrm{t}}-\mathrm{y}\right]-\gamma\left[\mathrm{u}_{\mathrm{t}}-\mathrm{u}\right]+\varepsilon_{\mathrm{t}}
$$

Artinya peningkatan pertumbuhan ekonomi akan meningkatkan inflasi, sebaliknya peningkatan tingkat pengangguran akan menurunkan tingkat inflasi. Komponen menetap dan komponen temporer dari core or underlying inflation masing-masing adalah inflasi periode sebelumnya $\left[\pi_{\mathrm{t}-1}\right]$ dan $\left[\lambda\left(\mathrm{y}_{\mathrm{t}}-\mathrm{y}\right)-\gamma\left(\mathrm{u}_{\mathrm{t}}-\mathrm{u}\right)\right]$.

Tiga konsep atau model (7-9) tentang komponen menetap dari core or underlying inflation dan komponen temporer memunculkan tiga pilihan tentang karakteristik inflasi. Persamaan (7) menjelaskan bahwa core or underlying inflation terdiri dari komponen menetap [ $\pi_{\mathrm{t}}^{\mathrm{t}}$ ] dan komponen temporer $\left[\lambda\left(\mathrm{y}_{\mathrm{t}}-\mathrm{y}\right)-\gamma\left(\mathrm{u}_{\mathrm{t}}-\mathrm{u}\right)\right]$. Persamaan (8) menjelaskan bahwa core or underlying inflation terdiri dari komponen menetap $\left[\theta \pi_{\mathrm{t}}{ }_{\mathrm{t}}+(1-\theta) \pi_{\mathrm{t}-1}\right]$ dan komponen temporer $\left[\lambda\left(\mathrm{y}_{\mathrm{t}}-\mathrm{y}\right)-\gamma\right.$ $\left(\mathrm{u}_{\mathrm{t}}-\mathrm{u}\right)$ ] dari core or underlying inflation. Persamaan (9) menjelaskan bahwa core or underlying inflation terdiri dari komponen menetap [ $\left.\pi_{\mathrm{t}-1}\right]$ dan komponen temporer $\left[\lambda\left(\mathrm{y}_{\mathrm{t}}-\mathrm{y}\right)-\gamma\left(\mathrm{u}_{\mathrm{t}}-\mathrm{u}\right)\right]$. Dari ketiga konsep ini ukuran core or underlying inflation komponen menetap merupakan 
ekspektasi inflasi. Ekspektasi inflasi merupakan penomena moneter sehingga pembentukan ekspektasi inflasi ditentukan oleh kebijakan moneter.

\section{Model Inkonsistensi Dinamis dan Kredibilitas Kebijakan Moneter}

Core or underlying inflation merupakan ekspektasi inflasi (Romer, 1996). Secara konseptual, pembentukan ekspektasi merupakan penomena inkonsistensi dinamis kebijakan moneter. Inkonsistensi dinamis kebijakan moneter bertujuan untuk meminimumkan social loss function pada tingkat inflasi optimal. Minimum social loss function dan model penawaran agregat Lucas, yaitu $\mathrm{L}=\left[\mathrm{y}_{\mathrm{t}}-\mathrm{y}_{\mathrm{t}}\right]^{2}+\beta\left[\pi_{\mathrm{t}}-\pi_{\mathrm{t}}^{\mathrm{o}}\right]^{2}$ dan $\mathrm{y}_{\mathrm{t}}=\mathrm{y}+\alpha\left[\pi_{\mathrm{t}}-\pi_{\mathrm{t}} \mathrm{t}\right]$, dimana y adalah tingkat harga fleksibel pada output keseimbangan, $\left[\mathrm{y}_{\mathrm{t}}-\mathrm{y}_{\mathrm{t}}\right]^{2}$ adalah kuadrat deviasi pertumbuhan output dari target pertumbuhan output $\left[\mathrm{y}^{\mathrm{o}} \mathrm{t}\right.$, dan $\beta$ adalah derajat keengganan terhadap kuadrat deviasi inflasi aktual dari target inflasi $\left[\pi_{\mathrm{t}}-\pi_{\mathrm{t}}^{\mathrm{o}}\right]^{2}$ relatif terhadap $\left[\mathrm{y}_{\mathrm{t}}-\mathrm{y}_{\mathrm{t}}\right]^{2}$ dari pembuat kebijakan. Substitusi kendala penawaran agregat pada social loss function akan menghasilkan:

$$
\begin{aligned}
& \operatorname{Min} \mathrm{L}=\left[\mathrm{y}+\alpha\left(\pi_{\mathrm{t}}-\pi_{\mathrm{t}}\right)-\mathrm{y}_{\mathrm{t}}\right]^{2}+\beta\left[\pi_{\mathrm{t}}-\pi_{\mathrm{t}}^{\mathrm{o}}\right]^{2} \\
& \text { FOC }\left[\pi_{\mathrm{t}}\right]: 2 \alpha\left[\mathrm{y}+\alpha\left(\pi_{\mathrm{t}}-\pi_{\mathrm{t}}\right)-\mathrm{y}_{\mathrm{t}}\right]+2 \beta\left[\mathrm{y}_{\mathrm{t}}-\mathrm{y}_{\mathrm{t}}\right]=0 \\
& \alpha\left[\mathrm{y}+\alpha\left(\pi_{\mathrm{t}}-\pi_{\mathrm{t}}^{\mathrm{e}}\right)-\mathrm{y}_{\mathrm{t}}^{\mathrm{o}}\right]+\beta\left[\pi_{\mathrm{t}}-\pi_{\mathrm{t}}^{\mathrm{o}}\right]=0 \\
& \alpha^{2} \pi_{\mathrm{t}}+\beta \pi_{\mathrm{t}}=\beta \pi_{\mathrm{t}}^{\mathrm{o}}+\alpha\left[\mathrm{y}_{\mathrm{t}}^{\mathrm{o}}-\mathrm{y}\right]+\alpha^{2} \pi_{\mathrm{t}}^{\mathrm{e}} \\
& {\left[\alpha^{2}+\beta\right] \pi_{\mathrm{t}}=\beta \pi_{\mathrm{t}}^{\mathrm{o}_{\mathrm{t}}}+\alpha\left[\mathrm{y}_{\mathrm{t}}-\mathrm{y}\right]+\alpha^{2} \pi_{\mathrm{t}}^{\mathrm{e}}} \\
& \pi_{\mathrm{t}}=\pi_{\mathrm{t}}^{\mathrm{o}}+\alpha /\left(\alpha^{2}+\beta\right)\left[\mathrm{y}_{\mathrm{t}}-\mathrm{y}\right]+\alpha^{2} /\left(\alpha^{2}+\beta\right)\left[\pi_{\mathrm{t}}-\pi^{\mathrm{o}_{\mathrm{t}}}\right]
\end{aligned}
$$

Dari (10) ditunjukkan bahwa perubahan inflasi aktual akibat perubahan ekspektasi inflasi adalah $\left[\mathrm{d} \pi_{\mathrm{t}} / \mathrm{d} \pi_{\mathrm{t}}\right]=\alpha^{2} /\left(\alpha^{2}+\beta\right)<1$. Inflasi optimal [ $\left.\pi_{\mathrm{t}}^{\mathrm{o}}\right]$ tercapai jika marginal cost dari peningkatan inflasi adalah $2 \beta\left[\pi_{\mathrm{t}}-\pi_{\mathrm{t}}^{\mathrm{o}}\right]=0$ dan marginal benefit peningkatan output adalah $2 \alpha$ $\left[\mathrm{y}+\alpha\left(\pi_{\mathrm{t}}-\pi_{\mathrm{t}} \mathrm{e}_{\mathrm{t}}-\mathrm{y}_{\mathrm{t}} \mathrm{t}\right]>0\right.$, yaitu pada tingkat $\pi_{\mathrm{t}}>\pi^{\mathrm{o}}{ }_{\mathrm{t}}$. Akan tetapi kondisi ini tidak pasti sehingga keseimbangan tercapai ketika $\pi_{\mathrm{t}}=\pi_{\mathrm{t}}$ dan akibatnya:

$$
\begin{aligned}
& \pi_{\mathrm{t}}=\pi^{\mathrm{o}}{ }_{\mathrm{t}}+\alpha /\left(\alpha^{2}+\beta\right)\left[\mathrm{y}_{\mathrm{t}}^{\mathrm{o}}-\mathrm{y}\right]+\alpha^{2} /\left(\alpha^{2}+\beta\right)\left[\pi_{\mathrm{t}} \mathrm{e}-\pi_{\mathrm{t}}^{\mathrm{o}}\right] \\
& \pi_{\mathrm{t}}=\pi_{\mathrm{t}}+\alpha /\left(\alpha^{2}+\beta\right)\left[\mathrm{y}_{\mathrm{t}}-\mathrm{y}\right]+\alpha^{2} /\left(\alpha^{2}+\beta\right)\left[\pi_{\mathrm{t}}-\pi^{\mathrm{o}} \mathrm{t}\right] \\
& \left(\alpha^{2}+\beta\right) \pi_{\mathrm{t}}-\alpha^{2} \pi_{\mathrm{t}}=\left(\alpha^{2}+\beta\right) \pi_{\mathrm{t}}+\alpha\left[\mathrm{y}_{\mathrm{t}}-\mathrm{y}\right]-\alpha^{2} \pi^{\mathrm{o}}{ }_{\mathrm{t}} \\
& \beta \pi_{\mathrm{t}}=\beta \pi^{\mathrm{o}_{\mathrm{t}}}+\alpha\left[\mathrm{y}_{\mathrm{t}}-\mathrm{y}\right] \\
& \pi_{\mathrm{t}} \mathrm{e}=\pi^{\mathrm{o}}{ }_{\mathrm{t}}+(\alpha / \beta)\left[\mathrm{y}_{\mathrm{t}} \mathrm{t}-\mathrm{y}\right]
\end{aligned}
$$

Persamaan (11) menjelaskan bahwa komponen menetap dari core or underlying inflation [ $\pi^{\mathrm{e}} \mathrm{t}$ adalah target inflasi $\left[\pi^{\mathrm{o}} \mathrm{t}\right]$ dan komponen temporer adalah kontribusi dari deviasi target pertumbuhan output $(\alpha / \beta)\left[\mathrm{y}_{\mathrm{t}}-\mathrm{y}\right.$ ]. Dari persamaan tersebut dijelaskan semakin besar kemiringan Phillips curve $[\alpha]$ semakin tinggi ekspektasi inflasi, sebaliknya semakin enggan pembuat kebijakan terhadap inflasi semakin rendah ekspektasi inflasi. Inkonsistensi dinamis kebijakan moneter menyatakan bahwa policymaker announce that inflation will equal to inflation target $\left[\pi^{\mathrm{o}} \mathrm{t}\right]$, and thereby cause expected inflation $\left[\pi_{\mathrm{t}}^{\mathrm{t}}\right]$ to equal an inflation target $\left[\pi^{\mathrm{o}} \mathrm{t}\right]$. But the policymaker can then set inflation according to:

$$
\pi_{\mathrm{t}}=\pi_{\mathrm{t}}^{\mathrm{o}}+\alpha /\left(\alpha^{2}+\beta\right)\left[\mathrm{y}_{\mathrm{t}}-\mathrm{y}\right]+\alpha^{2} /\left(\alpha^{2}+\beta\right)\left[\pi_{\mathrm{t}}-\pi_{\mathrm{t}} \mathrm{o}\right]
$$

Persamaan (12) menyatakan bahwa pembentukan ekspektasi inflasi tergantung pada target inflasi dan deviasi target pertumbuhan ekonomi. Substitusi ekspektasi inflasi (12) pada the expected-augmented Phillips curve akan menghasilkan baseline inflation, yaitu:

$$
\pi_{\mathrm{t}}=\pi_{\mathrm{t}}+\lambda\left[\mathrm{y}_{\mathrm{t}}-\mathrm{y}\right]-\gamma\left[\mathrm{u}_{\mathrm{t}}-\mathrm{u}\right]+\varepsilon_{\mathrm{t}}
$$




$$
=\pi^{\mathrm{o}_{\mathrm{t}}}+(\alpha / \beta)\left[\mathrm{y}_{\mathrm{t}}-\mathrm{y}\right]+\lambda\left[\mathrm{y}_{\mathrm{t}}-\mathrm{y}\right]-\gamma\left[\mathrm{u}_{\mathrm{t}}-\mathrm{u}\right]+\varepsilon_{\mathrm{t}}
$$

Persamaan (13) menjelaskan bahwa core or underlying inflation terdiri dari komponen menetap $\left[\pi^{\circ}\right]$, komponen temporer $[\alpha / \beta]\left[y^{o_{t}}-y\right]+\lambda\left[y_{t}-y\right]-\gamma\left[u_{t}-u\right]$. Inkonsistensi dinamis kebijakan moneter menyatakan bahwa core or underlying inflation bersumber dari target inflasi, deviasi pertumbuhan ekonomi dan deviasi tingkat pengangguran.

Dalam realitas, kredibilitas merupakan masalah pokok disain kebijakan moneter. Jika ekspansi moneter dapat meningkatkan output maka otoritas moneter secara rutin menekankan peningkatan penggunaan tenaga kerja di atas tingkat alamiah. Walsh (1995), Persson and Tabellini (1990; 1993) dan Svensson (1995) telah menunjukkan bahwa pendekatan implikasi normatif sangat penting untuk mendisain lembaga moneter. Kurva Phillips yang digunakan dengan tujuan meminimalkan social cost function, yaitu minimum $L=\left[\mathrm{y}_{\mathrm{t}}-\mathrm{y}_{\mathrm{t}}\right]^{2}+(\beta / 2) \pi_{\mathrm{t}}{ }^{2}$ dengan $\mathrm{y}_{\mathrm{t}}=\mathrm{y}+\alpha\left[\pi_{\mathrm{t}}-\pi_{\mathrm{t}}^{\mathrm{e}}\right]$. Substitusi penawaran agregat pada social cost function dan first-order condition social cost function terhadap inflasi $\left[\pi_{\mathrm{t}}\right]$ akan menghasilkan persamaan inflasi:

$$
\pi_{\mathrm{t}}=\alpha^{2} /\left(\alpha^{2}+\beta\right) \pi_{\mathrm{t}}+\alpha /\left(\alpha^{2}+\beta\right)\left[\mathrm{y}_{\mathrm{t}}^{\mathrm{o}}-\mathrm{y}\right]
$$

Komponen $\left[2 \alpha\left(\mathrm{y}+\alpha\left(\pi_{\mathrm{t}}-\pi_{\mathrm{t}}\right)-\mathrm{y}_{\mathrm{t}}^{\mathrm{o}}\right)\right]$ disebut marginal benefit dari peningkatan inflasi yang bernilai negatip dan komponen $\left[\beta \pi_{\mathrm{t}}\right]$ disebut marginal cost dari peningkatan inflasi. Persamaan (14) menjelaskan bahwa otoritas moneter memilih tingkat inflasi sebagai fungsi dari ekspektasi inflasi. Kredibilitas kebijakan moneter didefinisikan bias inflasi sama dengan nol atau $\pi_{\mathrm{t}}=\pi_{\mathrm{t}_{\mathrm{t}}}$ sehingga ekspektasi inflasi adalah

$$
\pi^{e_{t}}=(\alpha / \beta)\left[y^{o_{t}}-y\right]
$$

Substitusi ekspektasi inflasi (15) pada the expected-augmented Phillips curve akan menghasilkan model yang sama, artinya model kredibilitas kebijakan moneter sama dengan the expectedaugmented Phillips curve, yaitu:

$$
\begin{aligned}
\pi_{\mathrm{t}} & =\pi_{\mathrm{t}}+\lambda\left[\mathrm{y}_{\mathrm{t}}-\mathrm{y}\right]-\gamma\left[\mathrm{u}_{\mathrm{t}}-\mathrm{u}\right]+\varepsilon_{\mathrm{t}} \\
& =(\alpha / \beta)\left[\mathrm{y}_{\mathrm{t}}-\mathrm{y}\right]+\lambda\left[\mathrm{y}_{\mathrm{t}}-\mathrm{y}\right]-\gamma\left[\mathrm{u}_{\mathrm{t}}-\mathrm{u}\right]+\varepsilon_{\mathrm{t}} \\
& =\pi_{\mathrm{t}}+\lambda\left[\mathrm{y}_{\mathrm{t}}-\mathrm{y}\right]-\gamma\left[\mathrm{u}_{\mathrm{t}}-\mathrm{u}\right]+\varepsilon_{\mathrm{t}}
\end{aligned}
$$

Dari persamaan (16) ditunjukkan bahwa core or underlying inflation terdiri dari komponen menetap $\left[\pi_{t} e_{t}\right]$ dan komponen temporer $\left[\lambda\left(\mathrm{y}_{\mathrm{t}}-\mathrm{y}\right)-\gamma\left(\mathrm{u}_{\mathrm{t}}-\mathrm{u}\right)\right]$. Perbandingan persamaan (14) dengan (16) akan menjelaskan bahwa baseline inflation berbeda antara inkonsistensi dinamis kebijakan moneter dengan kredibilitas kebijakan moneter. Model inkonsistensi dinamis dan model kredibilitas kebijakan moneter merupakan nested model [model inkonsistensi dinamis mengandung model kredibilitas kebijakan moneter]. Model kredibilitas kebijakan moneter menyatakan bahwa core or underlying inflation bersumber dari ekspektasi inflasi, deviasi tingkat pertumbuhan ekonomi dan deviasi tingkat pengangguran $\left[\lambda\left(y_{t}-y\right)-\gamma\left(u_{t}-u\right)\right]$.

\section{SIMPULAN DAN REKOMENDASI}

Dari dekomposisi inflasi diketahui bahwa sumber tekanan inflasi adalah tiga sumber utama, yaitu inflasi inti atau core or underlying inflation, inflasi bukan inti atau non core inflation dan inflasi sesaat atau noise inflation. Inflasi bukan inti bersumber dari kebijakan pemerintah atau administered inflation, inflasi karena gejolak harga makanan atau volatile food inflation dan inflasi yang bersumber dari perdagangan atau traded goods inflation. Besar kecilnya sumbangan masing-masing sumber inflasi ditentukan oleh timbangan karakteristik inflasi terhadap inflasi.

Inflasi inti bersumber dari perubahan penawaran agregat, deviasi pertumbuhan ekonomi dengan pertumbuhan ekonomi, deviasi tingkat pengangguran dengan tingkat pengangguran 
alamiah, kejutan penawaran agregat. Deviasi pertumbuhan ekonomi dengan pertumbuhan ekonomi alamiah dan deviasi tingkat pengangguran dengan tingkat pengangguran alamiah merupakan komponen temporer dari inflasi inti. Menurut the expected-augmented Phillips curve, deviasi inflasi dengan ekspektasi inflasi bersumber dari deviasi tingkat pertumbuhan ekonomi dengan pertumbuhan ekonomi alamiah dan deviasi tingkat pengangguran dengan tingkat pengangguran alamiah.

Perbedaan dengan model inkonsistensi dinamis kebijakan moneter adalah bahwa ekspektasi inflasi ditentukan target inflasi dari penentu kebijakan dan deviasi target tingkat pertumbuhan ekonomi dengan tingkat pertumbuhan ekonomi alamiah. Oleh sebab itu menurut model inkonsistensi dinamis kebijakan moneter inflasi bersumber dari target inflasi, deviasi target tingkat pertumbuhan ekonomi dengan tingkat pertumbuhan alamiah, deviasi tingkat pertumbuhan ekonomi dengan tingkat pertumbuhan alamiah, deviasi tingkat pengangguran dengan tingkat pengangguran alamiah dan kejutan penawaran. Sedangkan model kredibilitas kebijakan moneter menyatakan bahwa inflasi bersumber dari ekspektasi inflasi dan deviasi target tingkat pertumbuhan ekonomi dengan tingkat pertumbuhan ekonomi alamiah.

Hubungan dekomposisi inflasi dengan model the expected-augmented Phillips curve, model inkonsistensi dinamis kebijakan moneter dan model kredibilitas kebijakan moneter adalah bahwa deviasi inflasi dengan ekspektasi inflasi bersumber dari inflasi non inti dan inflasi sesaat. Jika dihubungkan dengan model the expected-augmented Phillips curve, model inkonsistensi dinamis kebijakan moneter dan model kredibilitas kebijakan moneter maka inflasi non inti dan inflasi sesaat bersumber dari deviasi target pertumbuhan ekonomi dengan tingkat pertumbuhan alamiah, deviasi tingkat pertumbuhan ekonomi dengan tingkat pertumbuhan ekonomi alamiah, deviasi tingkat pengangguran dengan tingkat pengangguran alamiah dan kejutan penawaran atau supply shock.

Dari simpulan di atas diketahui bahwa keseimbangan antara target tingkat pertumbuhan ekonomi dan tingkat pertumbuhan ekonomi dengan tingkat pertumbuhan ekonomi alamiah, keseimbangan tingkat pengangguran dengan tingkat pengangguran alamiah akan menghasilkan deviasi tingkat inflasi dengan ekspektasi inflasi. Sehingga strategi kebijakan untuk stabilisasi inflasi adalah mendorong peningkatan pertumbuhan ekonomi untuk mencapai pertumbuhan alamiah atau menurunkan tingkat pengangguran ke tingkat pengangguran alamiah. Dari sisi dekomposisi inflasi, peningkatan pertumbuhan ekonomi ke pertumbuhan ekonomi alamiah atau penurunan tingkat pengangguran ke tingkat pertumbuhan alamiah menjaga stabilisasi harga-harga akibat kebijakan pemerintah, menjaga stabilisasi gejolak harga-harga makanan dan menjaga stabilitas harga-harga barang perdagangan.

Dari sisi kebijakan moneter, usaha menjaga stabilisasi gejolak harga-harga makanan dan stabilisasi harga-harga barang perdagangan adalah mengarahkan peningkatan jumlah uang beredar pada usaha mikro, kecil dan menengah karena usaha-usaha tersebut banyak menyerap tenaga kerja. Dari sisi kebijakan fiskal, usaha menjaga stabilisasi harga-harga akibat kebijakan pemerintah adalah menekan korupsi pada proyek-proyek pemerintah, sehingga peningkatan harga-harga komoditas strategis yang dihasilkan oleh pemerintah dapat ditekan seminimum mungkin, seperti peningkatan harga bahan bakar minyak dan energi lainnya.

\section{DAFTAR PUSTAKA}


Boediono. 1995. Seri Sinopsis Pengantar Ilmu Ekonomi No. 5: Ekonomi Moneter. Yogyakarta: BPFE Univeristas Gajah Mada.

Enders, W. 2004. Apllied Econometric Time Series. New York: John Wiley \& Sons, Inc.

Friedman, M. 1968. “The Role of Monetary Policy". American Economic Review 58: Pp. 1-17.

Gunawan, A. H. 1991. Anggaran Pemerintah dan Inflasi di Indonesia. Jakarta: Gramedia Pustaka Utama.

Lippi, F. 1999. Central Bank Independence, Targets and Credibility: Political and Economic Aspects of Delegation Arrangements for Monetary Policy. Cheltenham UK: Edward Elgar.

Lucas, R. E. Jr. 1972. "Expectation and the Neutrality of Money". Journal of Economic Theory 4: Pp. 103-24.

Lucas, R. E. Jr. 1973. "Some International Evidence on Output-Inflation Tradeoffs". American Economic Review 63: Pp. 326-34.

Lucas, R. E. Jr. 1981. Studies in Business-Cycle Theory. Cambridge: The MIT Press.

McCallum, B. T. 1989. Monetary Economics: Theory and Policy. New York: McMillan Publishing Company.

Obstfeld, M. and K. Rogoff, 1996. Foundations of International Macroeconomics. Cambridge: MIT Press.

Persson, T. and G. Tabellini. 1990. Macroeconomic Policy, Credibility and Politics. London: Harwood Publishers.

Persson, T. and G. Tabellini. 1993. "Designing Institution for Monetary Stability". Canergie Rochester Conference Series on Public Policy 39: 53-84.

Phelps, E. S. 1967. "Phillips Curves, Expectation of Inflation, and Optimal Unemployment over Time". Econometrica 34: Pp. 254-81.

Pindyck, R.S. and D. L. Rubinfeld. 1991. Econometric Models and Economic Forecasts. 3rd.ed. Singapore: McGraw-Hill International Edition.

Rogoff, K. 1985. “The Optimal Degree of Commitment to an Intermediate Monetary Target". Quarterly Journal of Economics 100: Pp. 1169-90.

Romer, D. 1996. Advance Macroeconomics. Singapore: McGraw-Hill Companies, Inc.

Svensson, L.E.O. 1995. Optimal Inflation Targets, Concervative Central Banks, and Linear Inflation Contracts. Discussion Paper 1249. Centre for Economic Policy Research [October].

Walsh, C. E. 1995. “Optimal Contracts for Central Bankers". American Economic Review 85: 150-67. 